\title{
STRUCTURE OF THE COMPLEX UCl 4 -2DMF BY VIBRATIONAL INFRARED SPECTROSCOPY AND DENSITY FUNCTIONAL THEORY
}

\author{
M. B. Shundalau ${ }^{a^{*}}$, A. I. Komyak ${ }^{\mathrm{a}}$, A. P. Zazhogin ${ }^{\mathrm{a}}$, \\ and D. S. Umreiko
}

UDC 539.19

\begin{abstract}
Structural models are designed and spectral characteristics are computed based on DFT calculations for a complex of $\mathrm{UCl}_{4}$ with two molecules of DMF $\left(U \mathrm{UCl}_{4} \cdot 2 \mathrm{DMF}\right)$. The calculations were carried out using a B3LYP hybrid functional in the LANL2DZ effective core potential approximation for the uranium atom and an allelectron basis set, cc-pVDZ, for all other atoms with partial force-field scaling. Two structural variants were found for the complex. The first structure is more stable, has $C_{i}$ symmetry, and is characterized by trans arrangement of ligands. The energy of the second structure of $C_{2}$ symmetry (with cis arrangement of ligands) is greater by $46 \mathrm{~kJ} / \mathrm{mol}$. The formation of the complex is shown to be accompanied by significant changes in the structure of $\mathrm{UCl}_{4}$. The obtained spectral characteristics are analyzed and compared with experimental data. The adequacy of the proposed models and the agreement between calculation and experiment are demonstrated.
\end{abstract}

Keywords: ab initio calculations, density functional theory, effective core potential, force-field scaling, infrared spectrum, $U \mathrm{Cl}_{4}, \mathrm{DMF}$, coordination complexes.

Introduction. Uranium is known to form chemical compounds in valences from 2 to 6 , of which the most stable species are hexa- and tetravalent uranium, U(VI) and U(IV). An example of stable compounds of the first species is the uranyl ion $\mathrm{UO}_{2}^{2+}$; of the second, uranium tetrahalides. They all form numerous coordination complexes with organic and inorganic ligands. Uranyl complexes are the most studied both experimentally and theoretically [1, 2]. Ligands containing electron-donating atoms with unshared electron pairs form the strongest complexes with U(IV). Examples of such molecules are polar organic solvents such as dimethylformamide (DMF), dimethylsulfoxide (DMSO), etc.

Electronic and vibrational absorption spectra of several coordination complexes of $\mathrm{UCl}_{4}$ were studied earlier [3-5]. Several hypotheses were made about the possible steric structure of these complexes. Herein the structure of a $\mathrm{UCl}_{4}$ complex with two organic ligands represented by DMF is discussed based on quantum-chemical calculations of the electronic structure and an analysis of previously obtained IR spectra [3, 4, 6].

Experimental and Calculation Method. IR absorption spectra of samples pressed in $\mathrm{KBr}$ pellets were recorded on a Bruker Vertex 70 spectrophotometer in the region $400-4000 \mathrm{~cm}^{-1}$. The equilibrium structure was optimized and the force field, eigen frequencies of vibrations, and intensities in IR spectra were calculated in a harmonic approximation using the applied quantum-chemical program GAMESS-US [7, 8]. The results were visualized using the MacMolPlt program [9]. The effective core potential (ECP) LANL2DZ that replaced the 78 inner electrons was used for the $U$ atom [10]. The DZ-basis sets that were specially developed for this ECP were employed for the remaining $\mathrm{U}$ electrons. The other atoms were described based on the standard all-electron basis cc-pVDZ [11]. The ECP and corresponding basis sets were generated using the Extensible Computational Chemistry Environment Basis Set Database [12-14]. The hybrid exchange-correlated functional B3LYP was also used in all calculations [15-17]. The initial force field that was obtained from calculations using the GAMESS program was then recalculated from units of mdyn/Å, $\mathrm{mdyn} \cdot \stackrel{\AA}{\mathrm{A}} / \mathrm{rad}^{2}$, and mdyn/rad (for coupling force constants of a bond with a bond, a bond with an angle, and an angle

*To whom correspondence should be addressed.

${ }^{a}$ Belarusian State University, 4 Nezavisimosti Ave., Minsk, 220030, Belarus; e-mail: shundalov@bsu.by;

${ }^{b}$ A. N. Sevchenko Institute of Applied Physical Problems, Belarusian State University, Minsk; e-mail: lab_dozator@mail.ru. Translated from Zhurnal Prikladnoi Spektroskopii, Vol. 79, No. 1, pp. 27-36, January-February, 2012. Original article submitted May 30, 2011. 

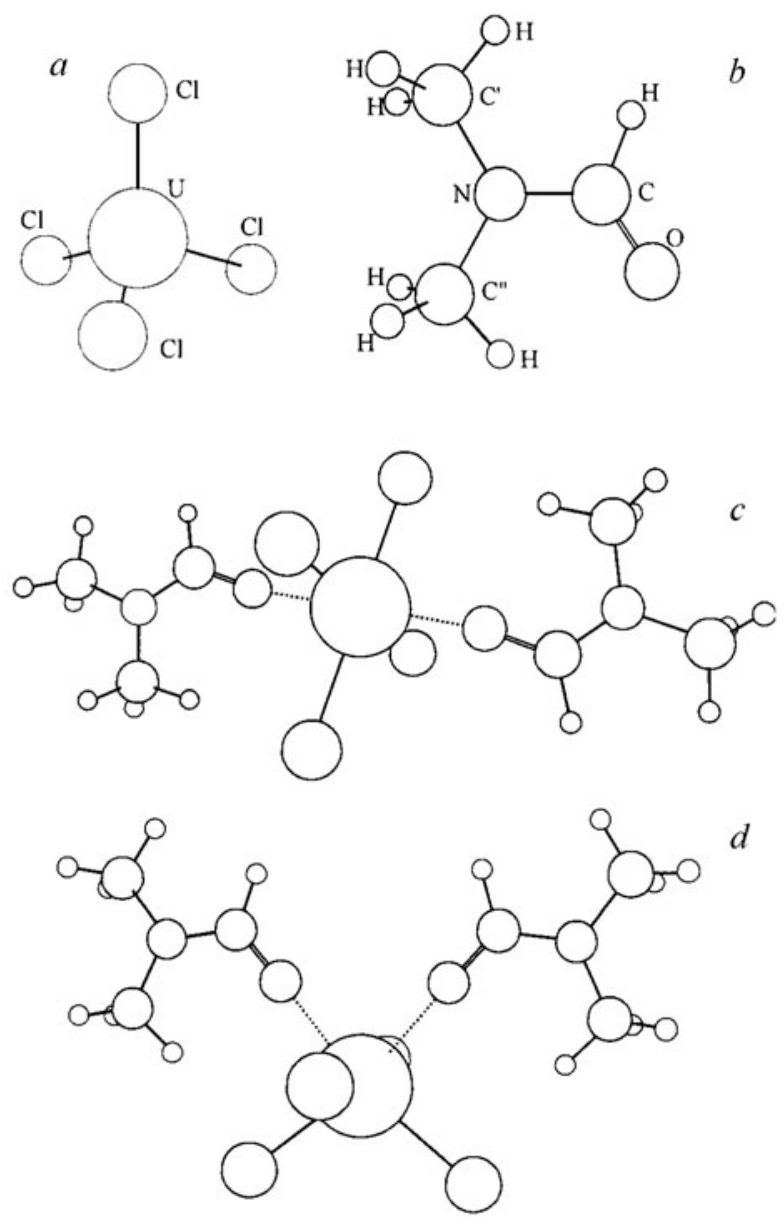

Fig. 1. Equilibrium configurations of $\mathrm{UCl}_{4}$ (a), $\mathrm{DMF}$ (b), and $\mathrm{UCl}_{4} \cdot 2 \mathrm{DMF}$ complexes of symmetry $C_{i}(\mathrm{c})$ and $C_{2}(\mathrm{~d})$.

with an angle) into units of $10^{6} \mathrm{~cm}^{-2}$ using the coefficients $1.5601,1.4313$, and 1.3131, respectively. Then, the force field was partially scaled. The resulting Hessian was used further to calculate the vibrational frequencies according to the published program [18].

Results and Discussion. Uranium tetrachloride $\left(U C l_{4}\right)$. It is currently supposed that the isolated $\mathrm{UCl}_{4}$ molecule (Fig. 1a) has a regular tetrahedral structure of symmetry $T_{d}$. Such a representation was formulated based on numerous experimental and theoretical investigations of both $\mathrm{UCl}_{4}$ and other uranium tetrahalides [19-32]. All four bond lengths are identical for this structure. Of the four fundamental vibrations (non-degenerate $v_{1}$ of symmetry $A_{1}$, doubly degenerate $v_{2}$ of symmetry $E$, and two triply degenerate $v_{3}$ and $v_{4}$ of symmetry $F_{2}$ ), only the last two (stretching and bending) are active in the IR spectrum. Thus, it is supposed that interaction with the environment (e.g., in an Ar matrix) or a Jahn-Teller effect can lower the symmetry of the equilibrium structure to $D_{2 d}, C_{3 v}$, or $C_{2 v}[19,27-29,33$ (review)]. The molecular bonds can have different lengths for symmetry lower than $T_{d}$. The irreducible representation $F_{2}$ is decomposed into the direct sum $B_{2} \oplus E$ for point group $D_{2 d}, A_{1} \oplus E$ for $C_{3 v}$, and $A_{1} \oplus B_{1} \oplus B_{2}$ for $C_{2 v}$. As a result, the appearance in the IR spectrum of bands for $v_{2}$ bending vibrations and splitting of the $v_{3}$ and $v_{4}$ bands associated with decomposition of irreducible representation $F_{2}$ can be expected upon lowering the symmetry to $D_{2 d}$ because vibrations $B_{2}$ and $E$ are allowed in the IR spectrum for this point group. For point group $C_{3 v}\left(A_{1}\right.$ and $E$ active in the IR), symmetric stretching vibration $A_{1}$ may appear in addition to those indicated above. For point group $C_{2 v}$ $\left(A_{1}, B_{1}\right.$, and $B_{2}$ active in the IR), bands $v_{3}$ and $v_{4}$ may split into three components with $v_{1}$ and $v_{2}$ also split in the IR spectrum (doubly degenerate representation $E$ is decomposed in $C_{2 \mathrm{v}}$ into the sum $A_{1} \oplus A_{2}$ ). 
Electron-diffraction and spectral studies of $\mathrm{UCl}_{4}$ in the gas phase at $T \approx 900 \mathrm{~K}$ were consistent with the regular tetrahedral structure and identical bond lengths $2.503 \pm 0.003 \AA$ [20]. The IR spectrum contained only two bands for stretching vibrations $v_{3}\left(330 \pm 20\right.$ [26], $337 \pm 3 \mathrm{~cm}^{-1}$ [20]), and bending $v_{4}\left(110 \pm 15\right.$ [26], $72 \pm 3 \mathrm{~cm}^{-1}$ [20]).

Results of DFT-calculations performed with the all-electron basis set using different functionals for the four variants $\left(T_{d}, D_{2 d}, C_{3 v}\right.$, and $\left.C_{2 v}\right)$ of the uranium tetrahalide structure $[23,25,30]$ confirmed the experimental data because the structure of symmetry $T_{d}$ had the lowest energy. The calculated $\mathrm{UCl}_{4}$ bond lengths were 2.494 (BP functional), 2.526 (BLYP), 2.496 (PBE), 2.509 (RPBE) [25], 2.513 (B3LYP), and $2.494 \AA$ A (PBE0) [23]. The frequencies of $v_{3}$ and $v_{4}$ were 357 and 81 (BP); 343 and 67 (BLYP); 349 and 78 (PBE); 335 and 75 (RPBE) [25]; 340, 338, 62 and 60 (B3LYP); 346, 344, 60, and $59 \mathrm{~cm}^{-1}$ (PBE0) [23] (bond lengths are given for the $T_{d}$ structure; frequencies, for $T_{d}$ [25] and $D_{2 d}$ [23]). It was noted during a discussion of the characteristics of model $\left(T_{d}\right.$ and $\left.D_{2 d}\right)$ IR spectra of $\mathrm{UF}_{4}$ [23] that their differences were so small that it was impossible to make an unambiguous conclusion on their basis about the symmetry of the $\mathrm{UF}_{4}$ equilibrium structure.

Equilibrium configurations of symmetry $D_{2 d}$ resulted from our calculations for isolated $\mathrm{UCl}_{4}$ and $\mathrm{UF}_{4}$. Bending mode $v_{2}$ for model symmetry $T_{d}$ had an imaginary frequency. The bond lengths for $\mathrm{UCl}_{4}$ were $2.543 \AA$ A. The $\mathrm{Cl}-$ $\mathrm{U}-\mathrm{Cl}$ bond angles were less than the tetrahedral value $\left(109.47^{\circ}\right.$ ) by $0.26^{\circ}$. Triply degenerate (for the $T_{d}$ model) stretching vibration $v_{3}$ was split into two components, i.e., doubly degenerate $E$ with $v=332.4 \mathrm{~cm}^{-1}$ and non-degenerate $B_{2}$ with $v=332.0 \mathrm{~cm}^{-1}$ (both vibrations had practically identical intensities in the IR spectrum). The frequency of fully symmetric stretching vibration $v_{1}$ was $324.2 \mathrm{~cm}^{-1}$ (inactive in the IR). Triply degenerate bending vibration $v_{4}$ was also split into two components with $v=50.2\left(B_{2}\right)$ and $49.7 \mathrm{~cm}^{-1}(E)$. The frequency of bending vibration $v_{2}$ was $46.2 \mathrm{~cm}^{-1}$. (All bending vibrations were split in the IR spectrum. However, the intensities of the corresponding absorption bands were 1-2 orders of magnitude less than those of stretching vibration $v_{3}$.). Analogous results were obtained for $\mathrm{UF}_{4}$. It is also noteworthy that the Hessian of the $\mathrm{UCl}_{4}$ model structure of lower symmetry $\left(C_{2 \mathrm{v}}\right)$ was also positively determined. However, in this instance the $\mathrm{UCl}$ bond lengths differed significantly $(2.522$ and $2.554 \AA$ ). The band of stretching vibration $v_{3}$ was split into three components with noticeably different frequencies $(338,330$, and $322 \mathrm{~cm}^{-1}$ ). This did not agree with the experimental data.

A more accurate reproduction of the experimental entropy values measured for $\mathrm{UCl}_{4}$ and $\mathrm{UF}_{4}$ in the gas phase at various temperatures can also supply an argument in favor of one of the structures (regular or slightly distorted tetrahedral) for the uranium tetrahalides [29,31,32]. The experimental entropy values for $\mathrm{UCl}_{4}$ at 650 and 700 $\mathrm{K}$ are $117.8 \pm 0.5$ [31] and $120.0 \pm 0.5 \mathrm{cal} /(\mathrm{mol} \cdot \mathrm{K})$ [32]. A DFT-calculation using the all-electron basis set for the $T_{d}$-model [25] demonstrated more than convincing agreement with the experiment. The values were 118.7 and 120.6 $\mathrm{cal} /(\mathrm{mol} \cdot \mathrm{K})$. However, our calculation for the $D_{2 d}$-model increased the entropy by $2 \%$ to 120.6 and $122.4 \mathrm{cal} /(\mathrm{mol} \cdot \mathrm{K})$. This argued in favor of the regular tetrahedral structure. However, a comparison of the corresponding entropy values for $\mathrm{UF}_{4}$ led to the opposite conclusion because the experimental values are $119.3 \pm 1$ [31] and $117.8 \pm 0.7 \mathrm{cal} /(\mathrm{mol} \cdot \mathrm{K})$ [29] at $1050 \mathrm{~K}$ and $120.5 \pm 0.5 \mathrm{cal} /(\mathrm{mol} \cdot \mathrm{K})$ at $1100 \mathrm{~K}$ [32] whereas those calculated previously [25] for the $T_{d}$-model were 117.2 and $118.4 \mathrm{cal} /(\mathrm{mol} \cdot \mathrm{K})$; calculated by us for the $D_{2 d}$-model, 119.9 and $121.1 \mathrm{cal} /(\mathrm{mol} \cdot \mathrm{K})$.

Thus, the structural and spectral-energetic characteristics of uranium tetrahalides calculated by us for the $D_{2 d^{-}}$ model do not in principle contradict the experimental results. Therefore, this structure can be used as the initial one for constructing a model of the molecular complex.

Dimethylformamide. The molecular structure of DMF has been studied several times both experimentally $[6,34-36]$ and theoretically $[6,37-40]$. However, the question of whether the molecular skeleton (i.e., the bonds to the $\mathrm{N}$ atom) is planar or pyramidal is still under discussion.

A non-planar equilibrium configuration for the molecular skeleton was obtained by optimizing the DMF geometry. A calculation of the Hessian confirmed the stability of this configuration (Fig. 1b). Table 1 presents the calculated DMF structural parameters and compares them with experimental electron-diffraction data for the gas phase [35]. The designations $\mathrm{C}^{\prime}$ and $\mathrm{C}^{\prime \prime}$ are used here and henceforth for the methyl $\mathrm{C}$ atoms located in the trans- and cis-

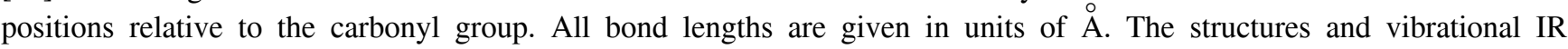
spectra of monomeric and five dimeric forms of DMF were analyzed in detail by us [6]. Figure 2 (curve 4) shows a portion of the DMF IR spectrum.

The complex. Two equilibrium structures (for trans- and cis-positions of the ligands) were found for the complex $\mathrm{UCl}_{4}$.2DMF. One of these had point symmetry $C_{i}$ (A), the other, $C_{2}$ (B) (Fig. $1 \mathrm{c}$ and d). According to the cal- 
Table 1. Structural Parameters of $\mathrm{UCl}_{4}, \mathrm{DMF}$, and Two Variants of the $\mathrm{UCl}_{4} \cdot 2 \mathrm{DMF}$

\begin{tabular}{|c|c|c|c|c|c|c||}
\hline \multirow{2}{*}{ Parameter } & \multicolumn{2}{|c|}{$\mathrm{UCl}_{4}$} & \multicolumn{2}{c|}{ DMF } & \multicolumn{2}{c||}{ Complex, calcn. } \\
\cline { 2 - 7 } & Calcn. & Expt. [20] & Calcn. [6] & Expt. [35] & A & B \\
\hline$r(\mathrm{UCl})$ & 2.543 & $2.503 \pm 0.003$ & - & - & 2.610 & 2.594 \\
\hline$r(\mathrm{C}=\mathrm{O})$ & - & - & 1.218 & $1.224 \pm 0.003$ & 1.248 & 1.244 \\
\hline$r(\mathrm{CN})$ & - & - & 1.368 & $1.391 \pm 0.007$ & 1.329 & 1.333 \\
\hline$r\left(\mathrm{NC}^{\prime}\right)$ & - & - & 1.447 & $1.453 \pm 0.004$ & 1.456 & 1.456 \\
\hline$r\left(\mathrm{NC}{ }^{\prime \prime}\right)$ & - & - & 1.452 & & 1.464 & 1.463 \\
\hline $\begin{array}{c}r(\mathrm{CH}), \\
\text { aldehyde }\end{array}$ & - & - & 1.118 & \multirow{2}{*}{$1.112 \pm 0.003$} & 1.104 & 1.106 \\
\hline $\begin{array}{c}r(\mathrm{CH}), \text { methyl } \\
\text { (average value })\end{array}$ & - & - & 1.103 & & 1.100 & 1.101 \\
\hline \begin{tabular}{c}
$r(\mathrm{U} . . \mathrm{O})$ \\
\hline
\end{tabular} & - & - & - & - & 2.358 & 2.414 \\
\hline
\end{tabular}

culation, the energy of complex B was $46.18 \mathrm{~kJ} / \mathrm{mol}$ greater than that of complex A. The shape of $\mathrm{UCl}_{4}$ changed significantly upon formation of the complex. This was associated with lowering of the local symmetry of $\mathrm{UCl}_{4}$ to $C_{2 h}$ for complex A and to $C_{2 v}$ for complex $\mathrm{B}$. The $\mathrm{UCl}_{4}$ molecular moiety was planar in complex $\mathrm{A}$. The bonds to the $\mathrm{U}$ atom (four $\mathrm{UCl}$ and two $\mathrm{U}$...O) formed a regular octahedral structure for complex A and one close to it for complex B. The UCl bonds in both variants of the complex were elongated significantly (by an average of $0.073 \AA$ ) and became non-equivalent (Table 1).

In contrast with the $\mathrm{UCl}_{4}$ moiety, the DMF ligand in the complex preserved its structure completely (Fig. 1b-d). The greatest changes were typical of the $\mathrm{C}=\mathrm{O}$ and $\mathrm{CN}$ bonds. The $\mathrm{C}=\mathrm{O}$ bonds were consistently elongated by 0.030 and $0.026 \AA$. The $\mathrm{CN}$ bonds in complexes $\mathrm{A}$ and $\mathrm{B}$ contracted by 0.039 and $0.035 \AA$. The $\mathrm{NC}^{\prime}$ and $\mathrm{NC}^{\prime \prime}$ bond lengths underwent smaller changes. They elongated by an average of $0.010 \AA$. A noticeable contraction of the aldehyde $\mathrm{CH}$ bonds (by an average of $0.013 \AA$ ) was also characteristic of dimeric DMF structures [6]. The significant increase of the $\mathrm{CH}$ stretching vibrations in the dimer or complex was not observed experimentally so this effect was apparently an artefact. The bond lengths of the methyl protons did not change significantly.

An analysis of the calculated vibrational spectra of DMF monomer and dimer [6] showed that use of the B3LYP/cc-pVDZ approximation increased the frequencies of the methyl stretching vibrations by $\sim 3 \%$; that of the carbonyl and aldehyde $\mathrm{CH}$, by $4 \%$. The frequencies of the other DMF stretching and also the bending vibrations increased less significantly. The stretching vibration frequencies of the molecular framework were less sensitive to scaling of the force constants. The calculated frequency of the antisymmetric $\mathrm{UCl}$ stretching vibration in isolated $\mathrm{UCl}_{4}$ was reduced by $1.5 \%$.

Thus, the force-constant matrix obtained from the DFT calculation was next partially scaled. The scaling factors were selected the same as for the DMF dimers [6]: $\sqrt{0.905}$ for the derivatives of energy along the $\mathrm{C}=\mathrm{O}$ and aldehyde $\mathrm{CH}$ bond lengths and $\sqrt{0.930}$ along other bond lengths with the exception of UCl.

Figure 2 shows portions of the experimental and two calculated (for models A and B) IR spectra of the $\mathrm{UCl}_{4} \cdot 2 \mathrm{DMF}$ complex. Table 2 compares the calculated frequencies and corresponding intensities of absorption bands with the experimental values. The experimental data for DMF are given for the liquid phase; the calculated data, for the most stable dimer [6]. The value for the most intense of the four components of the $\mathrm{C}=\mathrm{O}$ stretching vibration band in DMF is given [6]. Frequencies are given in units of $\mathrm{cm}^{-1}$; band intensities, in relative units. Experimental spectra of DMF and the complex in addition to the calculated DMF $\left(\mathrm{UCl}_{4}\right)$ spectrum were normalized to the intensity of the $\mathrm{C}=\mathrm{O}$ absorption band in the corresponding spectrum. The calculated spectra of the two complex variants were normalized to the intensity of the $\mathrm{C}=\mathrm{O}$ absorption band of complex A.

The spectrum of the complex (Fig. 2, curve 3), in contrast with that of pure DMF (curve 4), had a simpler structure. The intensities of the complex absorption bands in the fingerprint region were 2-5 times less than those in 


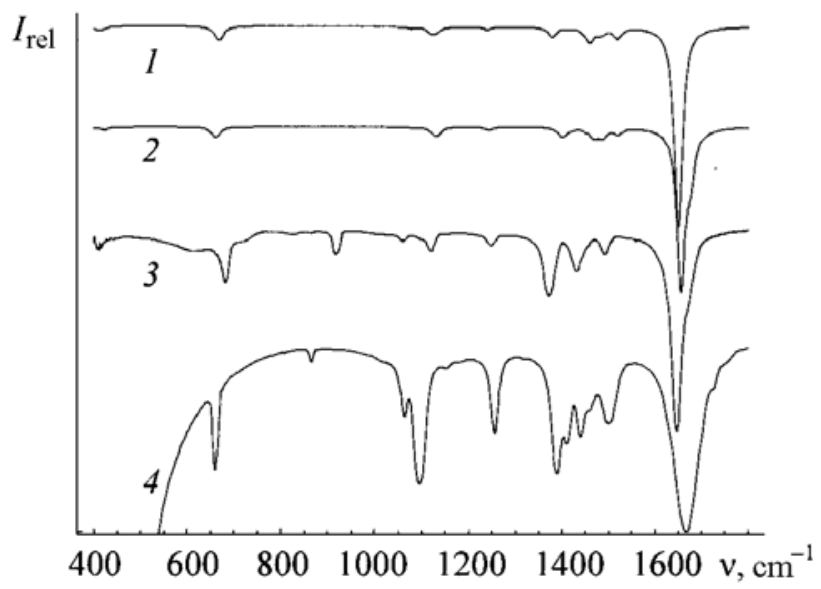

Fig. 2. IR spectra of the $\mathrm{UCl}_{4} \cdot 2 \mathrm{DMF}$ complex (1-3) and DMF (4) in the region $400-1800 \mathrm{~cm}^{-1}$; calculated for complexes $\mathrm{A}$ and $\mathrm{B}(1,2)$ and experimental $(3,4)$.

the DMF spectrum. This was a consequence of the redistribution of the spectral intensities as a result of the complexation. According to our calculation, the intensity (in $\mathrm{D}^{2} \cdot \mathrm{a} \cdot \mathrm{m} \cdot \mathrm{u}^{-1} \cdot \mathrm{A}^{-2}$ ) of the absorption band for the $\mathrm{C}=\mathrm{O}$ stretching vibration increased from 9.76 in the spectrum of the DMF monomer to 20.11 in that of the most stable dimer and to 57.27 in the spectrum of the complex. The intensities of the other absorption bands practically did not change. Thus, the relative intensities of these bands in the spectrum of the complex turned out to be less than in the spectrum of pure DMF. This was due to its simpler structure. Many combined frequencies and the weak overtone that were observed in the spectrum of pure DMF [6] did not appear in the spectrum of the complex because of the increased (relative to the spectrum of DMF) intensity of the $\mathrm{C}=\mathrm{O}$ fundamental mode.

The strongest bands in IR spectra of DMF and the complex corresponded obviously to $\mathrm{C}=\mathrm{O}$ stretching vibrations. The stretching frequency of free $\mathrm{C}=\mathrm{O}$ in the gas phase is $1715 \mathrm{~cm}^{-1}$ [41]. This band in the spectrum of a slightly concentrated solution of DMF in $\mathrm{CCl}_{4}$ has a simple envelope and is shifted to long wavelength $\left(1686.2 \mathrm{~cm}^{-1}\right)$ as the result of non-covalent interaction with solvent molecules [6]. The envelope of the $\mathrm{C}=\mathrm{O}$ absorption band in pure DMF has a complicated structure and can be represented as the sum of four Lorenz envelopes with centers at 1630.0, 1655.0, 1671.0, and $1689.5 \mathrm{~cm}^{-1}$ [6]. The various spectral shifts are due to several variants for combining DMF molecules into dimeric and polymeric structures in the liquid phase [6, 34, 39, 40].

The band for the stretching vibration of coordinated carbonyl in the spectrum of the complex was also asymmetric (Fig. 2) and could be represented as the sum of two Lorenz envelopes with half-widths $15 \mathrm{~cm}^{-1}$ and centers at 1646 and $1673 \mathrm{~cm}^{-1}$ and an intensity ratio 0.96:0.16. The carbonyl stretching vibration for model A of the $\mathrm{UCl}_{4} \cdot 2 \mathrm{DMF}$ complex of symmetry $C_{i}$ had a simple structure (curve 1) because one of the vibrations localized on the $\mathrm{C}=\mathrm{O}$ bonds $\left(1663 \mathrm{~cm}^{-1}\right)$ is forbidden by an alternate selection rule. The $\mathrm{C}=\mathrm{O}$ band in the spectrum of the complex was distinctly asymmetric (curve 3). This could be explained by a distortion of the $C_{i}$ structure by intermolecular interactions (which would be accompanied by relaxation of the alternate selection rule), the existence of complexes of a different shape (e.g., model $\mathrm{B}$ of symmetry $C_{2}$, the shape of the carbonyl band of which corresponds exactly to that observed), or the presence in the mixture of complexes with a different number of ligands (e.g., $\mathrm{UCl}_{4} \cdot 4 \mathrm{DMF}$ ). In the last instance, the alternate selection rule would also be relaxed and the carbonyl groups of different ligand pairs would exist in different environments because of steric hindrance. This in turn would cause different spectral shifts and asymmetric broadening of the $\mathrm{C}=\mathrm{O}$ absorption band.

Among other differences in IR spectra of the complex and that of pure DMF, the lower frequencies of several bending vibrations in the region $1000-1500 \mathrm{~cm}^{-1}$ that are localized on $\mathrm{CN}$ and $\mathrm{CH}$ bonds of methyls should be mentioned. These are $\delta_{\mathrm{as}} \mathrm{C}^{\prime} \mathrm{H}_{3}\left(\right.$ by $\left.8 \mathrm{~cm}^{-1}\right), \delta \mathrm{NCH}+\delta_{\mathrm{s}} \mathrm{C}^{\prime \prime} \mathrm{H}_{3}\left(\right.$ by $\left.11 \mathrm{~cm}^{-1}\right)$, and $\delta_{\mathrm{as}}\left(\mathrm{NC}^{\prime}+\mathrm{NC}^{\prime \prime}\right)\left(\right.$ by $\left.8 \mathrm{~cm}^{-1}\right)$. As a rule, the frequencies of $\mathrm{CH}_{3}$ swinging vibrations increased (Table 2). 
TABLE 2. Frequencies and Intensities in Experimental and Calculated IR Vibrational Spectra of $\mathrm{UCl}_{4}$ and DMF in the $\mathrm{UCl}_{4} \cdot 2 \mathrm{DMF}$

\begin{tabular}{|c|c|c|c|c|c|c|c|c|c|c|}
\hline \multirow{4}{*}{ Assignment } & \multicolumn{6}{|c|}{ Complex } & \multicolumn{4}{|c|}{$\mathrm{DMF}$ or $\mathrm{UCl}_{4}$} \\
\hline & \multicolumn{2}{|c|}{ Experiment } & \multicolumn{4}{|c|}{ Calculation } & \multicolumn{2}{|c|}{ Experiment } & \multicolumn{2}{|c|}{ Calculation } \\
\hline & \multirow{2}{*}{$v$} & \multirow{2}{*}{$I$} & \multicolumn{2}{|c|}{ A } & \multicolumn{2}{|c|}{ B } & \multirow{2}{*}{$v$} & \multirow{2}{*}{$I$} & \multirow{2}{*}{$v$} & \multirow{2}{*}{$I$} \\
\hline & & & $v$ & $I$ & $v$ & $I$ & & & & \\
\hline$v_{\text {as }} \mathrm{C}^{\prime \prime} \mathrm{H}_{3}$ & 3064 & 0.04 & $\begin{array}{l}3050 \\
3050 \\
\end{array}$ & $\begin{array}{c}0 \\
0.01 \\
\end{array}$ & $\begin{array}{l}3070 \\
3070\end{array}$ & $\begin{array}{l}0.02 \\
0.01\end{array}$ & - & - & $\begin{array}{l}3056 \\
3030\end{array}$ & $\begin{array}{l}<0.01 \\
<0.01\end{array}$ \\
\hline$v_{\mathrm{as}} \mathrm{C}^{\prime} \mathrm{H}_{3}$ & 3013 & 0.05 & $\begin{array}{l}3014 \\
3013\end{array}$ & $\begin{array}{c}0.01 \\
0\end{array}$ & $\begin{array}{l}3018 \\
3018\end{array}$ & $\begin{array}{l}<0.01 \\
<0.01\end{array}$ & 2998 & 0.07 & $\begin{array}{l}3004 \\
2997\end{array}$ & $\begin{array}{l}0.01 \\
0.01\end{array}$ \\
\hline$v_{\mathrm{as}} \mathrm{C}^{\prime \prime} \mathrm{H}_{3}$ & - & - & $\begin{array}{l}3007 \\
3006\end{array}$ & $\begin{array}{c}0 \\
0.01\end{array}$ & $\begin{array}{l}3000 \\
2999\end{array}$ & $\begin{array}{c}0.01 \\
<0.01\end{array}$ & 2959 & 0.11 & $\begin{array}{l}2961 \\
2954\end{array}$ & $\begin{array}{l}0.03 \\
0.03 \\
\end{array}$ \\
\hline $\mathrm{v}_{\mathrm{as}} \mathrm{C}^{\prime} \mathrm{H}_{3}$ & 2975 & 0.06 & $\begin{array}{l}2997 \\
2997\end{array}$ & $\begin{array}{c}0 \\
0.01\end{array}$ & $\begin{array}{l}2984 \\
2983 \\
\end{array}$ & $\begin{array}{c}0.01 \\
<0.01\end{array}$ & 2935 & 0.12 & $\begin{array}{l}2949 \\
2944\end{array}$ & $\begin{array}{l}0.07 \\
0.07\end{array}$ \\
\hline $\mathrm{v}_{\mathrm{s}} \mathrm{C}^{\prime \prime} \mathrm{H}_{3}$ & 2936 & 0.09 & $\begin{array}{l}2927 \\
2926 \\
\end{array}$ & $\begin{array}{c}0.03 \\
0 \\
\end{array}$ & $\begin{array}{l}2926 \\
2926 \\
\end{array}$ & $\begin{array}{l}0.01 \\
0.01 \\
\end{array}$ & 2917 & 0.11 & $\begin{array}{l}2902 \\
2898 \\
\end{array}$ & $\begin{array}{l}0.03 \\
0.08 \\
\end{array}$ \\
\hline$v_{\mathrm{s}} \mathrm{C}^{\prime} \mathrm{H}_{3}$ & 2892 & 0.06 & $\begin{array}{l}2918 \\
2918 \\
\end{array}$ & $\begin{array}{c}0.02 \\
0\end{array}$ & $\begin{array}{l}2915 \\
2915 \\
\end{array}$ & $\begin{array}{c}<0.01 \\
0.01\end{array}$ & 2885 & 0.09 & $\begin{array}{l}2891 \\
2888\end{array}$ & $\begin{array}{l}0.11 \\
0.10\end{array}$ \\
\hline$v \mathrm{CH}$ & 2867 & 0.05 & $\begin{array}{l}2906 \\
2905\end{array}$ & $\begin{array}{c}0 \\
0.03\end{array}$ & $\begin{array}{l}2880 \\
2879\end{array}$ & $\begin{array}{l}0.03 \\
0.02\end{array}$ & 2865 & 0.11 & $\begin{array}{l}2868 \\
2851\end{array}$ & $\begin{array}{l}0.02 \\
0.02 \\
\end{array}$ \\
\hline$v C=O$ & $\begin{array}{l}1673 \\
1646 \\
\end{array}$ & $\begin{array}{l}0.16 \\
0.96 \\
\end{array}$ & $\begin{array}{l}1663 \\
1650\end{array}$ & $\begin{array}{c}0 \\
1.00\end{array}$ & $\begin{array}{l}1676 \\
1656\end{array}$ & $\begin{array}{l}0.20 \\
0.78\end{array}$ & 1671 & 0.97 & $\begin{array}{l}1691 \\
1659 \\
\end{array}$ & $\begin{array}{l}1.00 \\
0.01\end{array}$ \\
\hline $\mathrm{vCN}$ & 1505 & shoulder & $\begin{array}{l}1520 \\
1519\end{array}$ & $\begin{array}{c}0 \\
0.05\end{array}$ & $\begin{array}{l}1520 \\
1519\end{array}$ & $\begin{array}{c}0.03 \\
<0.01\end{array}$ & 1511 & 0.22 & $\begin{array}{l}1515 \\
1513\end{array}$ & $\begin{array}{l}0.04 \\
0.02 \\
\end{array}$ \\
\hline $\begin{array}{c}\delta_{\mathrm{as}} \mathrm{C}^{\prime} \mathrm{H}_{3}+ \\
\delta_{\mathrm{as}} \mathrm{C}^{\prime \prime} \mathrm{H}_{3}\end{array}$ & 1493 & 0.12 & $\begin{array}{l}1487 \\
1486\end{array}$ & $\begin{array}{c}0 \\
0.02\end{array}$ & $\begin{array}{l}1488 \\
1488\end{array}$ & $\begin{array}{l}0.01 \\
0.01\end{array}$ & 1491 & 0.21 & $\begin{array}{l}1482 \\
1481\end{array}$ & $\begin{array}{l}0.02 \\
0.02\end{array}$ \\
\hline $\begin{array}{c}\delta_{\mathrm{as}} \mathrm{C}^{\prime} \mathrm{H}_{3}+ \\
\delta_{\mathrm{as}} \mathrm{C}^{\prime \prime} \mathrm{H}_{3}\end{array}$ & - & - & $\begin{array}{l}1478 \\
1478 \\
\end{array}$ & $\begin{array}{c}0 \\
0.02\end{array}$ & $\begin{array}{l}1486 \\
1485\end{array}$ & $\begin{array}{l}0.01 \\
0.01 \\
\end{array}$ & 1473 & 0.11 & $\begin{array}{l}1477 \\
1474 \\
\end{array}$ & $\begin{array}{l}0.02 \\
0.02 \\
\end{array}$ \\
\hline $\begin{array}{c}\delta_{\mathrm{as}} \mathrm{C}^{\prime} \mathrm{H}_{3}+ \\
\delta_{\mathrm{as}} \mathrm{C}^{\prime \prime} \mathrm{H}_{3}\end{array}$ & 1457 & shoulder & $\begin{array}{l}1463 \\
1459 \\
\end{array}$ & $\begin{array}{c}0 \\
0.07\end{array}$ & $\begin{array}{l}1471 \\
1468 \\
\end{array}$ & $\begin{array}{l}0.01 \\
0.04\end{array}$ & 1459 & 0.21 & $\begin{array}{l}1455 \\
1453 \\
\end{array}$ & $\begin{array}{l}0.01 \\
0.01\end{array}$ \\
\hline$\delta_{\mathrm{as}} \mathrm{C}^{\prime} \mathrm{H}_{3}$ & 1432 & 0.20 & $\begin{array}{l}1458 \\
1458\end{array}$ & $\begin{array}{c}0 \\
<0.01\end{array}$ & $\begin{array}{l}1455 \\
1455\end{array}$ & $\begin{array}{c}0 \\
<0.01\end{array}$ & 1440 & 0.37 & $\begin{array}{l}1446 \\
1445\end{array}$ & $\begin{array}{l}0.01 \\
0.01 \\
\end{array}$ \\
\hline $\begin{array}{c}\delta_{\mathrm{as}} \mathrm{C}^{\prime} \mathrm{H}_{3}+ \\
\delta_{\mathrm{as}} \mathrm{C}^{\prime \prime} \mathrm{H}_{3}\end{array}$ & 1410 & shoulder & $\begin{array}{l}1444 \\
1444\end{array}$ & $\begin{array}{c}<0.01 \\
0\end{array}$ & $\begin{array}{l}1452 \\
1452\end{array}$ & $\begin{array}{l}<0.01 \\
<0.01\end{array}$ & 1411 & 0.35 & $\begin{array}{l}1425 \\
1423 \\
\end{array}$ & $\begin{array}{l}0.01 \\
0.01\end{array}$ \\
\hline$\delta \mathrm{NCH}+\delta_{\mathrm{s}} \mathrm{C}^{\prime \prime} \mathrm{H}_{3}$ & 1377 & 0.19 & $\begin{array}{l}1419 \\
1417 \\
\end{array}$ & $\begin{array}{c}0 \\
<0.01\end{array}$ & $\begin{array}{l}1421 \\
1419 \\
\end{array}$ & $\begin{array}{c}<0.01 \\
0.01 \\
\end{array}$ & 1388 & 0.62 & $\begin{array}{l}1405 \\
1402 \\
\end{array}$ & $\begin{array}{c}<0.01 \\
0.02 \\
\end{array}$ \\
\hline$\delta_{\mathrm{s}} \mathrm{C}^{\prime \prime} \mathrm{H}_{3}$ & 1368 & 0.19 & $\begin{array}{l}1381 \\
1379\end{array}$ & $\begin{array}{c}0 \\
0.05\end{array}$ & $\begin{array}{l}1402 \\
1400\end{array}$ & $\begin{array}{c}<0.01 \\
0.04\end{array}$ & 1370 & shoulder & $\begin{array}{l}1386 \\
1376\end{array}$ & $\begin{array}{c}<0.01 \\
0.26\end{array}$ \\
\hline$\delta_{\mathrm{as}}\left(\mathrm{NC}^{\prime}+\mathrm{NC}^{\prime \prime}\right)$ & 1248 & 0.09 & $\begin{array}{l}1240 \\
1239\end{array}$ & $\begin{array}{c}0.01 \\
0\end{array}$ & $\begin{array}{l}1244 \\
1244\end{array}$ & $\begin{array}{c}0.01 \\
<0.01\end{array}$ & 1256 & 0.51 & $\begin{array}{l}1263 \\
1262 \\
\end{array}$ & $\begin{array}{l}0.02 \\
0.04\end{array}$ \\
\hline$\rho \mathrm{C}^{\prime} \mathrm{H}_{3}+\rho \mathrm{C}^{\prime \prime} \mathrm{H}_{3}$ & 1157 & 0.02 & $\begin{array}{l}1185 \\
1185\end{array}$ & $\begin{array}{c}<0.01 \\
0\end{array}$ & $\begin{array}{l}1186 \\
1186\end{array}$ & $\begin{array}{c}0 \\
<0.01\end{array}$ & 1152 & 0.19 & $\begin{array}{l}1189 \\
1185\end{array}$ & $\begin{array}{l}<0.01 \\
<0.01\end{array}$ \\
\hline$\rho C^{\prime} \mathrm{H}_{3}+\rho C^{\prime \prime} \mathrm{H}_{3}$ & 1120 & 0.11 & $\begin{array}{l}1133 \\
1132\end{array}$ & $\begin{array}{c}0 \\
0.02\end{array}$ & $\begin{array}{l}1132 \\
1132 \\
\end{array}$ & $\begin{array}{c}<0.01 \\
0.04\end{array}$ & 1104 & 0.35 & $\begin{array}{l}1142 \\
1138\end{array}$ & $\begin{array}{l}<0.01 \\
<0.01\end{array}$ \\
\hline$\rho \mathrm{C}^{\prime} \mathrm{H}_{3}+v \mathrm{CN}$ & 1094 & 0.03 & $\begin{array}{l}1122 \\
1121 \\
\end{array}$ & $\begin{array}{c}0 \\
0.03 \\
\end{array}$ & $\begin{array}{l}1123 \\
1120 \\
\end{array}$ & $\begin{array}{l}<0.01 \\
<0.01\end{array}$ & 1092 & 0.57 & $\begin{array}{l}1096 \\
1085 \\
\end{array}$ & $\begin{array}{c}<0.01 \\
0.32 \\
\end{array}$ \\
\hline
\end{tabular}


TABLE 2. (Continued)

\begin{tabular}{|c|c|c|c|c|c|c|c|c|c|c|}
\hline \multirow{4}{*}{ Assignment } & \multicolumn{6}{|c|}{ Complex } & \multicolumn{4}{|c|}{$\mathrm{DMF}$ or $\mathrm{UCl}_{4}$} \\
\hline & \multicolumn{2}{|c|}{ Experiment } & \multicolumn{4}{|c|}{ Calculation } & \multicolumn{2}{|c|}{ Experiment } & \multicolumn{2}{|c|}{ Calculation } \\
\hline & \multirow{2}{*}{$v$} & \multirow{2}{*}{$I$} & \multicolumn{2}{|c|}{$\mathrm{A}$} & \multicolumn{2}{|c|}{$\mathrm{B}$} & \multirow{2}{*}{$v$} & \multirow{2}{*}{$I$} & \multirow{2}{*}{$v$} & \multirow{2}{*}{$I$} \\
\hline & & & $v$ & $I$ & $v$ & $I$ & & & & \\
\hline$\rho C^{\prime} \mathrm{H}_{3}+\rho \mathrm{C}^{\prime \prime} \mathrm{H}_{3}$ & 1060 & 0.06 & $\begin{array}{l}1078 \\
1078 \\
\end{array}$ & $\begin{array}{c}0.01 \\
0\end{array}$ & $\begin{array}{l}1085 \\
1085 \\
\end{array}$ & $\begin{array}{c}<0.01 \\
0.01\end{array}$ & 1064 & 0.43 & $\begin{array}{l}1060 \\
1057\end{array}$ & $\begin{array}{l}0.02 \\
0.09 \\
\end{array}$ \\
\hline$\gamma \mathrm{CH}$ & 1020 & 0.02 & $\begin{array}{l}1015 \\
1013 \\
\end{array}$ & $\begin{array}{l}0 \\
0 \\
\end{array}$ & $\begin{array}{l}1004 \\
1001\end{array}$ & $\begin{array}{c}<0.01 \\
0\end{array}$ & 1020 & shoulder & $\begin{array}{l}1053 \\
1050\end{array}$ & $\begin{array}{c}0.01 \\
<0.01\end{array}$ \\
\hline$v_{\text {as }}$ uranyl $\mathrm{UO}_{2}^{2+}$ & $\begin{array}{l}924 \\
920 \\
914\end{array}$ & $\begin{array}{l}0.05 \\
0.07 \\
0.09\end{array}$ & - & - & - & - & - & - & - & - \\
\hline$v_{\mathrm{s}}\left(\mathrm{NC}^{\prime}+\mathrm{NC}^{\prime \prime}\right)$ & 863 & 0.02 & $\begin{array}{l}837 \\
836 \\
\end{array}$ & $\begin{array}{c}<0.01 \\
0\end{array}$ & $\begin{array}{l}839 \\
839 \\
\end{array}$ & $\begin{array}{l}<0.01 \\
<0.01\end{array}$ & 865 & 0.16 & $\begin{array}{l}857 \\
848\end{array}$ & $\begin{array}{l}0.01 \\
0.02 \\
\end{array}$ \\
\hline$v_{\mathrm{S}}$ uranyl $\mathrm{UO}_{2}^{2+}$ & $\begin{array}{l}835 \\
825 \\
814\end{array}$ & $\begin{array}{l}0.01 \\
0.01 \\
0.02\end{array}$ & & & & & - & - & - & - \\
\hline$\delta \mathrm{C}=\mathrm{O}+v \mathrm{NC}^{\prime}$ & 685 & 0.19 & $\begin{array}{l}672 \\
669 \\
\end{array}$ & $\begin{array}{c}0 \\
0.07 \\
\end{array}$ & $\begin{array}{l}664 \\
661 \\
\end{array}$ & $\begin{array}{l}0.01 \\
0.04 \\
\end{array}$ & 661 & 0.70 & $\begin{array}{l}649 \\
646 \\
\end{array}$ & $\begin{array}{l}0.02 \\
0.01 \\
\end{array}$ \\
\hline $\begin{array}{c}\text { Electronic } \\
\text { transition band }\end{array}$ & 620 & 0.12 & - & - & - & - & $\begin{array}{c}710 \pm 40 \\
{[26]}\end{array}$ & - & - & - \\
\hline$\sigma\left(\mathrm{NC}^{\prime}+\mathrm{NC}^{\prime \prime}\right)$ & 412 & 0.13 & $\begin{array}{l}416 \\
413 \\
\end{array}$ & $\begin{array}{c}0 \\
0.02 \\
\end{array}$ & $\begin{array}{l}424 \\
422 \\
\end{array}$ & $\begin{array}{l}0.01 \\
0.01\end{array}$ & $405[38]$ & - & $\begin{array}{l}384 \\
382 \\
\end{array}$ & $\begin{array}{l}<0.01 \\
<0.01\end{array}$ \\
\hline$\gamma \mathrm{C}=\mathrm{O}$ & - & - & $\begin{array}{l}382 \\
381 \\
\end{array}$ & $\begin{array}{c}0.02 \\
0 \\
\end{array}$ & $\begin{array}{l}378 \\
375 \\
\end{array}$ & $\begin{array}{c}0.01 \\
0\end{array}$ & $350 \quad[38]$ & - & $\begin{array}{l}367 \\
360 \\
\end{array}$ & $\begin{array}{c}0.03 \\
<0.01 \\
\end{array}$ \\
\hline$\rho \mathrm{C}=\mathrm{O}$ & - & - & $\begin{array}{l}330 \\
330 \\
\end{array}$ & $\begin{array}{c}0.1 \\
0\end{array}$ & $\begin{array}{l}330 \\
324 \\
\end{array}$ & $\begin{array}{l}0.01 \\
0.01\end{array}$ & $319[38]$ & - & $\begin{array}{l}331 \\
328 \\
\end{array}$ & $\begin{array}{l}0.03 \\
0.01\end{array}$ \\
\hline$\tau \mathrm{C}^{\prime} \mathrm{H}_{3}$ & - & - & $\begin{array}{l}326 \\
326 \\
\end{array}$ & $\begin{array}{c}<0.1 \\
0\end{array}$ & $\begin{array}{l}267 \\
267\end{array}$ & $\begin{array}{l}<0.01 \\
<0.01\end{array}$ & $224[38]$ & - & $\begin{array}{l}323 \\
320 \\
\end{array}$ & $\begin{array}{c}0.02 \\
<0.01\end{array}$ \\
\hline$v_{\mathrm{as}} \mathrm{UCl}$ & - & - & 293 & 0.05 & 298 & 0.05 & 337 [20] & - & 332 & 0.11 \\
\hline$v_{\mathrm{s}} \mathrm{UCl}$ & - & - & 288 & $<0.1$ & 291 & $<0.01$ & - & - & 324 & 0 \\
\hline$v_{\text {as }} \mathrm{UCl}$ & - & - & 279 & 0.04 & 269 & 0.05 & $337[20]$ & - & 332 & 0.11 \\
\hline$\tau \mathrm{C}^{\prime \prime} \mathrm{H}_{3}$ & - & - & $\begin{array}{l}271 \\
271 \\
\end{array}$ & $\begin{array}{c}0 \\
0.01 \\
\end{array}$ & $\begin{array}{l}297 \\
297\end{array}$ & $\begin{array}{c}<0.01 \\
0.01\end{array}$ & $215[38]$ & - & $\begin{array}{l}309 \\
300\end{array}$ & $\begin{array}{l}<0.01 \\
<0.01\end{array}$ \\
\hline$v_{\text {as }} \mathrm{UCl}$ & - & - & 247 & 0.01 & 262 & 0.02 & 337 [20] & - & 332 & 0.11 \\
\hline$\gamma \mathrm{U} \ldots \mathrm{O}=\mathrm{C}$ & - & - & $\begin{array}{l}247 \\
245 \\
\end{array}$ & $\begin{array}{l}0 \\
0 \\
\end{array}$ & $\begin{array}{l}242 \\
239 \\
\end{array}$ & $\begin{array}{l}0 \\
0 \\
\end{array}$ & - & - & - & - \\
\hline v U...O & - & - & $\begin{array}{l}207 \\
189\end{array}$ & $\begin{array}{c}0.03 \\
0\end{array}$ & $\begin{array}{l}188 \\
160\end{array}$ & $\begin{array}{c}0.01 \\
<0.01\end{array}$ & - & - & - & - \\
\hline$\delta$ O...U... & - & - & $\begin{array}{l}128 \\
125 \\
\end{array}$ & $\begin{array}{c}<0.01 \\
0\end{array}$ & $\begin{array}{l}134 \\
123 \\
\end{array}$ & $\begin{array}{l}<0.01 \\
<0.01\end{array}$ & - & - & - & - \\
\hline$\delta \mathrm{ClUCl}$ & - & - & $\begin{array}{l}117 \\
114 \\
\end{array}$ & $\begin{array}{c}<0.01 \\
0 \\
\end{array}$ & $\begin{array}{l}124 \\
115 \\
\end{array}$ & $\begin{array}{l}<0.01 \\
<0.01 \\
\end{array}$ & 72 [20] & - & 50 & $<0.01$ \\
\hline
\end{tabular}

Note. $v_{\mathrm{s}}, v_{\mathrm{as}}$, and $\delta_{\mathrm{as}}$ are stretching and bending symmetric and antisymmetric vibrations; $\rho-$ swinging; $\gamma-$ out-of-plane; $\sigma-$ scissors; and $\tau$ - torsional vibrations. 
The absorption of the complex in the region $800-1000 \mathrm{~cm}^{-1}$ should be analyzed separately. The weak band at $\sim 863 \mathrm{~cm}^{-1}$, a stronger analog of which $\left(865 \mathrm{~cm}^{-1}\right)$ was seen in the spectrum of pure DMF, was interpreted as a symmetric stretching vibration of $\mathrm{NC}^{\prime}$ and $\mathrm{NC}^{\prime \prime}$ bonds. Other asymmetric broad bands at $\sim 918$ and $826 \mathrm{~cm}^{-1}$ were missing in spectra of pure DMF and should be considered a consequence of the complexation [3]. Both these absorption bands could be represented as sums of three Lorenz envelopes. The first resulted from bands centered at 914, 920, and $924 \mathrm{~cm}^{-1}$ in a 0.091:0.070:0.050 ratio; the second, at 814, 825, and 835 in a 0.016:0.014:0.013 ratio. It is well known that antisymmetric and symmetric $\mathrm{O}=\mathrm{U}=\mathrm{O}$ stretching vibrations appear in these regions in vibrational spectra of $\mathrm{UO}_{2}^{2+}$ (uranyl) chlorides [1,2]. It can be assumed that the studied samples contained a small impurity of the uranyl salt that was comparatively readily formed due to oxidation of U(IV) to U(VI) in air [3].

The strong band at $685 \mathrm{~cm}^{-1}$ for a combination vibration of $\mathrm{C}=\mathrm{O}$ bending and $\mathrm{NC}^{\prime}$ stretching was shifted to higher frequency by $24 \mathrm{~cm}^{-1}$ in the complex spectrum relative to its position in the spectrum of pure DMF. This shift was also due to complexation and was predicted in calculated spectra of both complex models. The broad weak band with a diffuse maximum at $620 \mathrm{~cm}^{-1}$ apparently corresponded to an electronic transition between a lower and one of the excited sublevels of the ${ }^{3} \mathrm{H}_{4}$ ground state of $\mathrm{U}^{4+}$ [26].

The splitting of the $\mathrm{UCl}$ antisymmetric stretching vibration in the complex into three components was accompanied by a long-wavelength shift of the frequencies $\left(293,279\right.$, and $247 \mathrm{~cm}^{-1}$ in model A and 298, 269, and $262 \mathrm{~cm}^{-}$ ${ }^{1}$ in model B). Analogous results $\left(292,277\right.$, and $\left.250 \mathrm{~cm}^{-1}\right)$ were obtained by us from spectral studies of model A of the complex $\mathrm{UCl}_{4} \cdot 2 \mathrm{DMSO}$ and provided confirmation of the present results [4]. The long wavelength spectrum of this complex exhibited a strong band that could be represented as the sum of three envelopes centered at 270, 256, and $235 \mathrm{~cm}^{-1}$. According to the calculation, the region below $115 \mathrm{~cm}^{-1}$ contained another 11 combination bending vibrations of complicated shape for the ligands and $\mathrm{UCl}_{4}$. The frequencies and intensities of these vibrations were weak and were not included in Table 2.

Conclusion. Quantum-chemical modeling of the structure of the complex of $\mathrm{UCl}_{4}$ with two electron-donating DMF ligands predicted the existence of two stable configurations of symmetry $C_{i}$ and $C_{2}$ with trans- and cis-positions of the ligands, respectively. The first variant of the complex turned out to be more stable. The structure of the DMF molecule remained practically unchanged upon complexation whereas the shape of the $\mathrm{UCl}_{4}$ moiety was significantly distorted. The $\mathrm{UCl}_{4}$ moiety became planar in the complex with an inversion center. Its local symmetry was reduced to $C_{2 h}$. The symmetry of the $\mathrm{UCl}_{4}$ moiety in the complex with the two-fold symmetry axis was reduced to $C_{2 v}$. Characteristics of vibrational IR spectra that were calculated based on the proposed structures reproduced adequately the experimental data as a whole. Thus, the examined structures provided a useful model for complexes of electron-donating ligands with uranium halides as the central moiety.

Acknowledgments. We thank N. P. Vileishikova for help with recording spectra.

\section{REFERENCES}

1. L. V. Volod'ko, A. I. Komyak, and D. S. Umreiko, Uranyl Compounds [in Russian], 1, Bel. Gos. Univ., Minsk (1981).

2. D. S. Umreiko, T. A. Dik, A. P. Zazhogin, A. I. Komyak, and V. V. Syt'ko, Spectra and Structure of Uranyl Complexes [in Russian], Bel. Gos. Univ., Minsk (2004).

3. A. P. Zazhogin, A. I. Komyak, D. S. Umreiko, and A. A. Lugovskii, Vestn. Beloruss. Gos. Univ., Ser. 1: Fiz., Mat., Inf., No. 3, 3-7 (2009).

4. A. P. Zazhogin, A. I. Komyak, and D. S. Umreiko, Zh. Prikl. Spektrosk., 75, No. 5, 729-732 (2008).

5. A. I. Komyak, A. P. Zazhogin, D. S. Umreiko, and A. A. Lugovskii, Zh. Prikl. Spektrosk., 76, No. 2, 182-187 (2009).

6. M. B. Shundalau, P. S. Chibirai, A. I. Komyak, A. P. Zazhogin, M. A. Ksenofontov, and D. S. Umreiko, Zh. Prikl. Spektrosk., 78, No. 3, 351-361 (2011).

7. M. W. Schmidt, K. K. Baldridge, J. A. Boatz, S. T. Elbert, M. S. Gordon, J. H. Jensen, S. Koseki, N. Matsunaga, K. A. Nguyen, S. J. Su, T. L. Windus, M. Dupuis, and J. A. Montgomery, J. Comput. Chem., 14, 13471363 (1993).

8. http://www.msg.ameslab.gov/GAMESS/GAMESS.html

9. B. M. Bode and M. S. Gordon, J. Mol. Graphics Modell., 16, 133-138 (1998). 
10. L. R. Kahn, P. J. Hay, and R. D. Cowan, J. Chem. Phys., 68, 2386-2397 (1978).

11. T. H. Dunning, Jr., J. Chem. Phys., 90, 1007-1023 (1989).

12. https://bse.pnl.gov/bse/portal

13. D. Feller, J. Comput. Chem., 17, 1571-1586 (1996).

14. K. L. Schuchardt, B. T. Didier, T. Elsethagen, L. Sun, V. Gurumoorthi, J. Chase, J. Li, and T. L. Windus, J. Chem. Inf. Model., 47, 1045-1052 (2007).

15. A. D. Becke, J. Chem. Phys., 98, 5648-5652 (1993).

16. C. Lee, W. Yang, and R. G. Parr, Phys. Rev. B: Condens. Matter Mater. Res., 37, 785-789 (1988).

17. P. J. Stephens, F. J. Devlin, C. F. Chabalowski, and M. J. Frisch, J. Phys. Chem., 98, 11623-11627 (1994).

18. V. V. Sivchik and K. M. Grushetskii, Zh. Prikl. Spektrosk., 19, No. 2, 317-319 (1973).

19. I. R. Beattie, P. J. Jones, K. R. Millington, and A. D. Wilson, J. Chem. Soc. Dalton Trans., 2759-2762 (1988).

20. A. Haaland, K.-G. Martinsen, O. Swang, H. V. Volgen, A. S. Booij, and R. J. M. Konings, J. Chem. Soc. Dalton Trans., 185-190 (1995).

21. A. Haaland, K.-G. Martinsen, and R. J. M. Konings, J. Chem. Soc. Dalton Trans., 2473-2474 (1997).

22. R. J. M. Konings and D. L. Hildenbrand, J. Alloys Cmpd., 271-273, 583-586 (1998).

23. E. R. Batista, R. L. Martin, and P. J. Hay, J. Chem. Phys., 121, 11104-11111 (2004).

24. J. E. Peralta, E. R. Batista, G. E. Scuseria, and R. L. Martin, J. Chem. Theory Comput., 1, 612-616 (2005).

25. Y. Zhang, Y. Li, and C. Hao, Mol. Phys., 106, 1907-1912 (2008).

26. J. B. Gruber and H. G. Hecht, J. Chem. Phys., 59, 1713-1720 (1973).

27. P. M. Boerrigter, J. G. Snijders, and J. M. Dyke, J. Electron Spectrosc. Relat. Phenom., 46, $43-53$ (1988).

28. V. N. Bukhmarina, Y. B. Predtechensky, and L. D. Shcherba, J. Mol. Struct., 218, 33-38 (1990).

29. R. J. M. Konings, A. S. Booij, A. Kovacs, G. V. Girichev, N. I. Giricheva, and O. G. Krasnova, J. Mol. Struct., 378, 121-131 (1996).

30. Y. Zhang, Y. Li, and Y. Cao, J. Mol. Struct.: THEOCHEM, 864, 85-88 (2008).

31. D. L. Hildenbrand, Pure Appl. Chem., 60, 303-307 (1988).

32. D. L. Hildenbrand, K. H. Lau, and R. D. Brittain, J. Chem. Phys., 94, 8270-8275 (1991).

33. M. Hargittai, Chem. Rev., 100, 2233-2301 (2000).

34. H. Ohtaki, S. Itoh, T. Yamaguchi, S. Ishiguro, and B. M. Rode, Bull. Chem. Soc. Jpn., 56, 3406-3409 (1983).

35. G. Schultz and I. Hargittai, J. Phys. Chem., 97, 4966-4969 (1993).

36. H. Borrmann, I. Persson, M. Sandstrom, and C. M. V. Stalhandske, J. Chem. Soc. Perkin Trans. 2, 393-402 (2000).

37. X. Zhou, J. A. Krauser, D. R. Tate, A. S. VanBuren, J. A. Clark, P. R. Moody, and R. Liu, J. Phys. Chem., 100, 16822-16827 (1996).

38. C. M. V. Stalhandske, J. Mink, M. Sandstrom, I. Papai, and P. Johansson, Vib. Spectrosc., 14, $207-227$ (1997).

39. R. Vargas, J. Garza, D. A. Dixon, and B. P. Hay, J. Am. Chem. Soc., 122, 4750-4755 (2000).

40. J. Ireta, J. Neugebauer, and M. Scheffler, J. Phys. Chem. A, 108, 5692-5698 (2004).

41. T. C. Jao, I. Scott, and D. Steele, J. Mol. Spectrosc., 92, 1-17 (1982). 